\title{
Job characteristics and life satisfaction in the EU: A domains-of-life approach
}

\author{
Clara Viñas-Bardolet, Mònica Guillen-Royo, Joan Torrent-Sellens
}

\begin{abstract}
Working life has come to permeate every domain of life. Characteristics once thought to affect only the job domain have become important determinants of how people assess their daily lives. This article explores the influence of job characteristics on satisfaction with several life domains in 28 EU countries, asking: 1) What is the relationship between job characteristics and satisfaction with work and other domains of life? 2) Is the job domain more important for life satisfaction than other domains of life? Additionally, we apply a domains-of-life perspective to investigate possible differences in these relationships between high- and low-skilled workers, using data on whitecollar workers from the third European Quality of Life Survey (3EQLS) and multiple Ordinary Least Squares (OLS) regressions to estimate the models.

Work-life balance and perceived job (in)security emerge as important determinants of satisfaction regarding all domains and both types of workers studied. Satisfaction in the work domain ranks fourth in contributing to overall life satisfaction, after the standard of living, family life and social life domains. This relatively low direct contribution to life satisfaction of the work domain is particularly visible among low-skilled workers. We conclude with a discussion of the implications for workers' wellbeing of the increasing insecurity in the job market and the fact that meaning is often sought through work despite the effects of poor work-life balance on most lifedomains.
\end{abstract}

Key words: domains of life satisfaction; job satisfaction; life satisfaction; white-collar workers; working conditions; work-life balance conflict 


\section{Introduction}

On an everyday basis, the work domain exerts a pervasive influence, conditioning our relationships with others, our opportunities for exercise and outdoor recreation, and our physical and emotional health, among many other factors. This influence stems from specific job characteristics and from the time spent at work and in commuting (Eurofound and ILO 2017). The influence of work across life-domains has been studied by classical sociologists and organizational theorists such as Durkheim (1947) with his theory of division of labour, and Marx $(1976,1927)$ in his theories of labour process and alienation. Also most recent researchers such as Near et al. (1980) have studied the relationship between aspects of work life and non-work domains. Kalleberg (2009) notes that work is a core activity in society: "perhaps only kin relationships are as influential in people's everyday lives" as work. However, the literature on subjective wellbeing ${ }^{1}$ has paid relatively little attention to the linkages between work characteristics and non-work domains.

This paper analyses the importance of working life on the subjective wellbeing of workers in EU countries, through two main mechanisms. The first relates to how various work characteristics affect job satisfaction and other domains, such as accommodation, health, education, standard of living, family and social life. The second concerns the extent to which job satisfaction contributes to life satisfaction, as compared with the contributions of the above-mentioned six domains. As earlier research has indicated differences in the determinants of job satisfaction for different types of workers (Batinic et al. 2010; Bujacz et al. 2017; Silla et al. 2005), we explore the extent to which these differences apply to how job characteristics relate to domain satisfaction, and how job satisfaction contributes to life satisfaction among low-skilled and high-skilled white-collar workers.

\footnotetext{
${ }^{1}$ Following Gough and McGregor (2007) we understand "wellbeing" as an umbrella term comprehending both objective and subjective approaches. Concerning subjective wellbeing, we draw on Diener (1984) and Diener et al. (1999) in considering its hedonic and cognitive dimensions, the former linked to positive and negative effects and the latter to life satisfaction.
} 
The study focuses on white-collar workers ${ }^{2}$ in the top five occupations in the standard classification. ${ }^{3}$ By 2012, they represented $67 \%$ of the EU labour force, ${ }^{4}$ and their numbers are increasing each year. Distinguishing between low- and high-skilled workers, Bujacz et al. (2017) and Batinic (2010) and Eurofound (2014a) have shown important differences between highly skilled and low-skilled workers concerning their experiences and appraisal of the intrinsic qualities of their jobs. This is supported by research indicating that the determinants of job satisfaction differ for knowledge workers and non-knowledge workers (Huang, 2011; Viñas-Bardolet et al. 2018) a classification that expands systems based on occupational categories to encompass educational levels and skills. ${ }^{5}$

Our study, like that of Rojas (2007), follows a domains-of-life approach, whereby personal and socioeconomic characteristics are seen as influencing life satisfaction through their effect on various life-domains. It extends Rojas' work by adding job characteristics as explanatory variables in addition to the usual socio-demographic factors. Our study also links to the work of van Praag and colleagues (2003) on life satisfaction, as we assume that the latter is a function of satisfaction with various domains. However, unlike the van Praag study, we focus on the relationship between work-related variables and satisfaction with work and non-work domains, ignoring other domainspecific predictors such as square meters per capita in housing.

First, we present the literature background describing the importance of the work domain, then describe the domains-of-life approach to subjective wellbeing (SWB) and how work-related factors have been studied in the SWB literature. Then, after outlining the characteristics and hypotheses of this study, we introduce the European Quality of Life Survey (EQLS) and the data used in the analysis. Next we present the empirical models and describe the main results for the

\footnotetext{
${ }^{2}$ The transformation from mass production to flexible production, characteristic of the post-Ford era, has also altered the political and economic structure of society and its production systems. Thompson (2003) found that flexible production dramatically reduced the demand for unskilled labour, requiring workers with flexible specialization and multi-skilled (social and technical skills). The number of unskilled industrial workers has been falling for nearly thirty years. This decrease is reflected in the transformation of the workforce, with the growth of managerial and professional services, and the increase in white-collar jobs to the detriment of blue-collar jobs: towards to a service economy, with a decline in the mass production and manufacturing sectors. This change also implies global competition, flexible production systems, flatter and more flexible organizational structures, with the emphasis on innovation, diversification and subcontracting (Avis, 1996; Brown and Lauder, 1992).

${ }^{3}$ Legislators, senior officials and managers, professionals and technicians, associate professionals, clerks, service workers, and shop and market sales workers.

${ }^{4}$ Eurostat Labour force data: http://ec.europa.eu/eurostat/web/lfs/data/ accessed 06/12/2017.

${ }^{5}$ Knowledge workers' are defined as a new type of white-collar workers who generally possess higher academic degrees, greater skill levels or knowledge, working in the three highest standard occupational classifications (managers, professionals, associate professionals) (Huang, 2011).
} 
general sample and for the subsamples of high- and low-skilled workers. We conclude with a discussion of the findings and some broader policy implications.

\section{Theory and hypotheses}

\subsection{The domains-of-life approach to SWB}

Two main perspectives characterize approaches to life satisfaction in the literature on subjective wellbeing: "top-down” and "bottom-up" (Diener 1984; Erdogan et al. 2012; Headey et al. 1991; Loewe et al. 2014). The former sees life satisfaction as a function of stable personal or socioeconomic features (Erdogan et al. 2012) and of situational influences such as life events (Diener 1996). By contrast, the basic assumption in the "bottom-up" perspective is that an individual's overall life satisfaction depends on satisfaction in many separate and specific areas of life, which can be classified into different life domains (Cummins, 1996; Easterlin, 2006; Rojas, 2006; van Praag \& Ferrer-i-Carbonell, 2004; van Praag et al., 2003). This perspective encompasses various theories of life satisfaction that conceive of domain satisfactions as "needs" - such as multiple discrepancy theory (Michalos 1985), the needs hierarchy theory (Maslow 1970) or the bottom-up spillover theory (Andrews and Withey 1976; Campbell et al. 1976). As Sirgy et al. (2010) note concerning bottom-up spillover theory, life satisfaction is situated at the top of a pyramid: life satisfaction is determined by satisfaction with life domains, located one level below; in turn, life domains are influenced by lower levels of life characteristics that may be common or specific to each given domain.

Life domains are relevant to how people assess their own lives. The fact that individual satisfaction can be quantitatively evaluated with respect to these separate domains makes scientific analysis possible (van Praag and Ferrer-i-Carbonell 2004). In his survey of the literature on life satisfaction, Cummins (1996) operated with seven life domains: material wellbeing, health, productivity, intimacy, safety, community, and emotional wellbeing; otherwise, however, the number has varied from one study to another. ${ }^{6}$ Rojas (2006, p. 469) has highlighted how restricting the number of domains to specific categories may be misleading: "the enumeration and

\footnotetext{
${ }^{6}$ For an exhaustive list of life domains used in other studies see Loewe et al. (2014, pp. 74-75).
} 
demarcation of the domains of life is arbitrary. Nevertheless, the number of domains must be manageable and domains should refer to clearly separable information."

Although domains should be easy to identify and perceive as separate dimensions, they are also interrelated and overlapping. van Praag et al. (2003) see this interrelatedness as stemming from the fact that domains have common explanatory variables, which leads them to suggest that general satisfaction may be seen as an aggregate of satisfaction in the six domains. Rojas (2006) expands this perspective by arguing that life satisfaction might not be indicated by a simple average of domains satisfaction, as people may differ in the weight they allocate to each domain. Additionally, and because there may be diminishing or increasing marginal returns when one domain rises or declines, Rojas proposes using alternative specifications such as semi-logarithm, logarithm-logarithm or the constant elasticity of substitution (CES) relationship to model the contribution of each domain to life satisfaction. Other scholars have recommended asking respondents to appraise the importance of each domain, and then using the resulting scores as weights (Hsieh, 2004, 2016). Hsieh's findings indicate that domain importance plays a significant role in determining the type of relationship between life satisfaction and domain satisfaction at the individual level, and that weighting of domain importance should be incorporated in any study on the topic.

The domains-of-life approach sees socioeconomic, structural and demographic variables as influencing life satisfaction through their impact on life domains. Regarding the work domain, for example, Drobnič (2010) and colleagues found that working conditions contribute to high levels of job satisfaction, which in turn serve to increase life satisfaction. Conversely, Near and Rechner (1993) compared variations in predictors of life satisfaction among ten Western European countries, focusing on work variables as predictors. Using working conditions, living conditions, job satisfaction and non-work satisfaction (an index created from thirteen other life-domains) to predict life satisfaction, they found job satisfaction to be a weak predictor of life satisfaction compared with non-work satisfaction. An additional study by Rode and Near (2005) found that job satisfaction was positively related to overall life satisfaction; this relation emerged when variables concerning work characteristics (inter alia, working hours) and demographic characteristics were controlled for. 
Figure 1. Bottom-up theory of life satisfaction

\section{Life satisfaction}

\section{Domains of life:}

Job, Health, Accommodation, Education, Standard of living, Family life, Social life

\section{Socio-economic + Job characteristics}

\section{(occupation type, working hours, having an unlimited contract, work-life} balance conflict, flexible schedule and job insecurity).

Source: Authors' elaboration following Sirgy et al. (2010), Figure 1.

Using a domains-of-life approach, our study explores the importance of work-related variables in explaining overall life satisfaction in 28 EU countries, 2011-2012. We assume not only that job characteristics are important for job satisfaction, but also that their impact extends to other domains of life. Thus, we consider that job characteristics usually studied for their importance solely to the work domain are also significant determinants of how people assess their everyday experience. We ask: "What is the relationship between job characteristics and workers' satisfaction with the domains of accommodation, health, education, standard of living, family and social life in EU countries?" This leads us to our first hypothesis:

H1: Job characteristics can explain reported levels of satisfaction across all life-domains, not only concerning job satisfaction.

Previous work has studied job characteristics by distinguishing between occupational types, often analysing the differences between high- and low-skilled workers. A Eurofound (2014b) study based on data from the fifth European Working Conditions Survey (EWCS) showed that workers in mid-skilled manual and low-skilled occupations reported lower earnings, lower career prospects and lower intrinsic job quality, but high levels of working-time quality - whereas workers in highskilled occupations fared relatively well on almost all job-quality indicators except quality of 
working time. In another study, Eurofound (2014a) found considerable differences between occupations with regard to workers' influence over working-time arrangements. High-skilled workers reported considerable influence here, whereas low-skilled workers reported far less autonomy in scheduling their working time.

In their study of seven Western European countries, Gallie and Russell (2009) found that higher-skilled workers tend to experience greater work-family conflict. Also McGinnity and Calvert (2009) noted higher work-life conflict among professionals compared to nonprofessionals; this they saw as partially explained by the fact that professionals work longer hours and experience more work pressure than other groups. However, it should be noted that this effect seems to remain even after accounting for these two potentially mediating variables.

Job insecurity is another important factor. Silla et al. (2005) found that low-skilled workers reported higher levels of job insecurity than did high-skilled workers, and noted that job insecurity depended mainly on employability or employees' perceptions of the chances of finding another job if they should lose their present one. From the literature indicating differences among types of workers concerning their working conditions, we hypothesize that:

H2: High- and low-skilled workers differ in the extent to which job characteristics explain domain-satisfaction.

\subsection{Importance of the work domain}

At the turn of the $20^{\text {th }}$ century, in a context of rapid economic development, classical sociologists and organizational theorists such as Marx and Durkheim understood socioeconomic institutions as interrelated and inseparable. They saw the work domain as highly important in society, pervading other aspects of social life. As Near and colleagues (1980) put it:

Marx, for one major example, argued that the advent of capitalism resulted in alienating conditions, associated with work itself as well as its surrounding circumstances, which in turn produced alienative behavior among workers, both on and off the job [Marx \& Engels, 1939]. Durkheim [1947] suggested that basic work-related divisions of labor produced interdependence among institutions, thus serving, ideally, to integrate the members of society. (Near et al., 1980, p. 415) 
More recently, sociologists such as Sennett (1998) have noted how post-Fordism ${ }^{7}$ and its labour needs are opposed to family needs. The need for flexibility and adaptation to changes at work requires great personal involvement, to the detriment of family life - leading to an imbalance between the values required for a successful working life and those required for a stable family life. Likewise, Perrons (2003) has indicated that, in this system of work organization, new working patterns and new technologies have allowed the temporal and spatial boundaries of paid work to be extended, eroding the boundaries and collective rhythms of working life and the concepts and realities of a "fixed" working day. This may be seen as positive for some workers (e.g. as an opportunity to work) but as negative for others (e.g. work invading the home and family sphere). What is clear is that the characteristics of work overstep the boundaries of the job domain, greatly influencing other domains of life.

Empirical studies of the differing contributions of domains satisfaction to life satisfaction among workers accord a significant role to the work domain (Loewe et al. 2014; Near and Rechner 1993; van Praag et al. 2013). In their study of West German and East German workers, van Praag and colleagues (2003) found that finances, health and job satisfaction were the three main determinants in explaining overall life satisfaction, whereas housing, leisure-time and satisfaction with one's surroundings appeared less important. In a study based on a sample of Chilean workers, similar results were obtained by Loewe and colleagues (2014). They found that, having controlled for age and gender, satisfaction with one's financial situation emerged as the dominant predictor of overall life satisfaction. Satisfaction with family, work, and health was also relevant, but leisuretime or social relationships were not found to have statistically significant effects on life satisfaction.

In samples encompassing the general population, findings on the importance of the job domain are less conclusive. For example, Rojas (2007), studying a representative sample of 579 observations in Mexico, found that life satisfaction could be predicted mainly by family, economic and personal satisfaction, whereas job and health seemed less important. By contrast, in his life-

\footnotetext{
7 "Post-Fordism" refers to the dominant system of economic production, consumption, and associated socioeconomic phenomena in most industrialized countries since the late 20th century. It describes an approach to work organization that relies on flexibility, adaptation and innovation (Heery \& Noon, 2008).
} 
cycle study of overall life satisfaction in the USA, Easterlin (2006) found that financial satisfaction, followed by job satisfaction and family life, were the central domains in explaining life satisfaction, with health as a less important determinant.

Studies investigating the contribution of job satisfaction to life satisfaction have generally confirmed the importance of the work domain, particularly when focusing on workers and when the individual's position in the life-cycle is accounted for (Easterlin, 2006; Loewe et al., 2014; van Praag et al., 2003). Nevertheless, none of the studies reviewed find that the work domain is the greatest contributor to life satisfaction. In principle, that would call into question the relative importance of the work domain as indicated by sociologists and organizational theorists: however, it could also be taken to strengthen our $\mathrm{H} 1$ on the relevance of job characteristics for other life domains. Thus, work characteristics could be seen as contributing to life satisfaction through their relationship with job satisfaction and through their effect on satisfaction with other domains of life - in turn, leading to the following hypothesis:

H3: Job satisfaction is a significant contributor to life satisfaction, but work characteristics have a broader impact on life satisfaction through their relationship with non-work domains.

As noted, there is evidence in the literature on subjective wellbeing to suggest that high- and low-skill workers differ regarding how job characteristics affect their subjective wellbeing (Argyle \& Martin, 1991; Batinic et al., 2010). In general, low-skilled workers have less autonomy and less flexible time arrangements than high-skilled workers (Batinic et al. 2010; Bujacz et al. 2017; Silla et al. 2005), and more highly skilled and highly paid jobs are associated with greater job satisfaction (Argyle \& Martin, 1991). In addition, greater life and job satisfaction has been found for high-skilled white-collar workers (top 3 ISCO codes); see Argyle and Martin (1991) and Batinic et al. (2010). Thus, our fourth hypothesis:

H4: There are significant differences between high- and low-skilled workers as regards the contribution of job satisfaction to life satisfaction. 


\section{Data and methods}

\subsection{The survey}

Our study draws on the third European Quality of Life Survey (3EQLS) from the Dublin-based European Foundation for the Improvement of Living and Working Conditions (2014) encompassing 28 EU countries for the period 2011-2012. The EQLS is conducted every four years; it is a unique survey that examines the objective circumstances of the lives of EU citizens, their feelings and assessments of their situation, and that provides a remarkable amount of quality information for scholars of subjective wellbeing. For example, in studying job-related determinants of life satisfaction in EU countries, Drobnič (2010) has drawn on data from the first EQLS (2003); and Voicu (2015) has used the three waves of EQLS (2003, 2007 and 2011) to study the priming effects of domain-satisfaction questions on responses to ensuing satisfaction questions and the question capturing overall life satisfaction.

Of the populations included in the EQLS survey, we focus on white-collar employees, defined as all employees working in the top five standard occupational classifications (managers, professionals, associate professionals, clerical support workers, and services/sales workers), aged 18 or over, whose usual place of residence at the time of data collection was in any of the EU countries. We excluded 132 individuals who could not report satisfaction in each of the domains of life under consideration, as these are the dependent variables of the study and important determinants of life satisfaction. Our final sample consisted of 7,624 employees.

\subsection{Variables and descriptive analysis}

Table 1 presents the list of indicators used in the empirical analysis, the corresponding description and some descriptive statistics. Our dependent variables are life satisfaction (the dependent variable of the study) and the seven domains-of-life satisfaction studied in the Third EQLS: job, accommodation, health, education, standard of living, family life and social life. The use of these seven domains for the analysis is in line with previous studies ${ }^{8}$ such as Rojas (2006, 2007), Sirgy et al. (2010), van Praag and Ferrer-i-Carbonell (2004), van Praag et al. (2003). As shown in Table 1 , the mean value for life satisfaction is 7.37; the highest mean value across the domains is 8.08 for the domains of family life and of health (7.99), and the standard of living satisfaction domain

\footnotetext{
${ }^{8}$ For an exhaustive list of life domains used in other studies see Loewe et al. (2014, pp. 74-75).
} 
is lowest (7.21). The domains-of-life classification is close to that of van Praag and Ferrer-iCarbonell (2004), Rojas (2006) and Loewe et al. (2014).

Regarding independent and control variables we follow Rojas (2007) and van Praag et al. (2003), and use gender, age, age squared, education and income as main socio-demographic variables. We also include other variables widely studied in the literature on life domains and job satisfaction, such as health status and working hours (Clark 2010; Clark and Oswald 1996; van Praag et al. 2003); job insecurity, flexible schedule, type of contract and work-life balance conflict, in line with the work of Sousa-Poza and Sousa-Poza (2000), Dolan et al. (2008) and Erdogan et al. (2012). These work characteristics have been widely used in studies of life satisfaction. Among others, Drobnič et al. (2010) and Silla et al. (2005) found that job insecurity was a major negative factor influencing life satisfaction. Drobnič et al. (2010) also found that the effects of working conditions on overall life satisfaction were not symmetric: "bad jobs" had a stronger effect on reducing life satisfaction than "good jobs" had in increasing it. Additionally, we agree with Maertz and Boyar (2010) and Erdogan et al. (2012) on the importance of workers' experience of conflict or balance between work and non-work domains, and have included a work-life balance conflict variable to capture its relevance.

Our sample of white-collar employees is defined by type of occupation according to the International Standard Classification of Occupations, ISCO-88. ${ }^{9}$ In line with Eurofound (2010), we distinguish two categories of employees here:

- high-skilled white collar (ISCO codes 1,2 and 3): legislators, senior officials and managers, professionals and technicians, and associate professionals;

- low-skilled white collar (ISCO codes 4 and 5): clerks, service workers, and shop and market sales workers.

This classification has been used in other works, such as Lopes et al. (2014).

Table 1 shows the mean and standard deviation of life satisfaction and satisfaction in each lifedomain according to the two sub-samples. High-skilled workers report better life satisfaction (7.61) than the low-skilled workers (7.16) and greater satisfaction regarding all domains of life.

Family life, and then education and health, are the top satisfaction domains for the highly skilled workers, whereas family life followed by health and accommodation are rate highest among

\footnotetext{
${ }^{9}$ ISCO detailed classification: http://www.ilo.org/public/english/bureau/stat/isco/index.htm [accessed 29/01/18].
} 
low-skilled workers. Standard of living is the lowest-rated item for low-skilled workers, as is standard of living together with social life satisfaction for highly skilled workers.

Table A (in the Appendix) shows Pearson's correlations across satisfaction in the seven domains of life. All correlations are positive; some are relatively high. Even though correlations are statistically significant, each separate domain of life can provide additional useful information (Rojas 2006, p. 494). Additionally, Table B (in the Appendix) shows Pearson's correlations across the control and independent variables and domains of life; and Table C (in the Appendix) shows responses to each of the domains and life satisfaction on the Likert-type scales (1 to 10).

Table D (also in the Appendix), compares the means of the domains-of-life results for the two groups of workers. Regarding all domains, highly skilled workers emerge as more satisfied than low-skilled workers. 
Table 1. Indicators: definitions and descriptive statistics

\begin{tabular}{|c|c|c|c|c|c|c|c|c|c|}
\hline \multirow[b]{2}{*}{ Variable } & \multirow[b]{2}{*}{ Description } & \multirow[b]{2}{*}{ Min } & \multirow[b]{2}{*}{ Max } & \multicolumn{2}{|c|}{ Full sample } & \multicolumn{2}{|c|}{ High-skilled } & \multicolumn{2}{|c|}{ Low-skilled } \\
\hline & & & & $\mathbf{N}$ & Mean (SD) & Obs. & Mean (SD) & $\mathbf{N}$ & Mean (SD) \\
\hline Life Satisfaction & $\begin{array}{l}\text { All things considered, how satisfied would you say you are with } \\
\text { your life these days? From 1, 'very dissatisfied' to } 10 \text {, 'very } \\
\text { satisfied'. }\end{array}$ & 1 & 10 & 7,624 & $7.37(1.80)$ & 3,635 & $7.61(1.64)$ & 3,989 & $7.16(1.92)$ \\
\hline Job & $\begin{array}{l}\text { How satisfied are you with your present job? From } 1 \text {, 'very } \\
\text { dissatisfied' to } 10 \text {, 'very satisfied'. }\end{array}$ & 1 & 10 & 7,624 & $7.62(1.94)$ & 3,635 & $7.97(1.74)$ & 3,989 & $7.29(2.04)$ \\
\hline Accommodation & $\begin{array}{l}\text { How satisfied are you with your accommodation? From 1, 'very } \\
\text { dissatisfied' to } 10 \text {, 'very satisfied'. }\end{array}$ & 1 & 10 & 7,624 & $7.78(1.91)$ & 3,635 & $7.95(1.80)$ & 3,989 & $7.64(1.98)$ \\
\hline Health & $\begin{array}{l}\text { How satisfied are you with your health? From 1, 'very } \\
\text { dissatisfied' to } 10 \text {, 'very satisfied'. }\end{array}$ & 1 & 10 & 7,624 & $7.99(1.82)$ & 3,635 & $8.11(1.73)$ & 3,989 & $7.89(1.90)$ \\
\hline Education & $\begin{array}{l}\text { How satisfied are you with your education? From } 1 \text {, 'very } \\
\text { dissatisfied' to } 10 \text {, 'very satisfied' }\end{array}$ & 1 & 10 & 7,624 & $7.60(2.05)$ & 3,635 & $8.11(1.80)$ & 3,989 & $7.14(2.15)$ \\
\hline Standard of living & $\begin{array}{l}\text { How satisfied are you with your present standard of living? From } \\
1 \text {, 'very dissatisfied' to } 10 \text {, 'very satisfied'. }\end{array}$ & 1 & 10 & 7,624 & $7.21(1.98)$ & 3,635 & $7.60(1.81)$ & 3,989 & $6.85(2.06)$ \\
\hline Family life & $\begin{array}{l}\text { How satisfied are you with your family life? From } 1 \text {, 'very } \\
\text { dissatisfied' to } 10 \text {, 'very satisfied'. }\end{array}$ & 1 & 10 & 7,624 & $8.08(1.91)$ & 3,635 & $8.19(1.84)$ & 3,989 & $7.98(1.96)$ \\
\hline Social life & $\begin{array}{l}\text { How satisfied are you with your social life? From } 1 \text {, 'very } \\
\text { dissatisfied' to } 10 \text {, 'very satisfied'. }\end{array}$ & 1 & 10 & 7,624 & $7.48(1.91)$ & 3,635 & $7.60(1.82)$ & 3,989 & $7.37(1.98)$ \\
\hline Male & 1 if worker is male. & 0 & 1 & 7,624 & $0.39(0.49)$ & 3,635 & $0.49(0.50)$ & 3,989 & $0.31(0.46)$ \\
\hline Age & Age of worker. & 18 & 78 & 7,624 & $42.00(10.95)$ & 3,635 & $42.95(10.74)$ & 3,989 & $41.11(11.06)$ \\
\hline $\operatorname{Age}^{\wedge} 2$ & Age of worker squared. & 3.24 & 90.25 & 7,624 & $18.84(9.36)$ & 3,635 & $19.63(9.44)$ & 3,989 & $18.12(9.22)$ \\
\hline Education level & $\begin{array}{l}\text { What is the highest level of education you completed? (Seven } \\
\text { ISCED codes: from 'pre-primary education' to second stage of } \\
\text { tertiary education'.) }\end{array}$ & 0 & 6 & 7,591 & $3.84(1.18)$ & 3,628 & $4.40(1.03)$ & 3,963 & $3.33(1.06)$ \\
\hline
\end{tabular}


Income

Health status

High-skilled worke

Working hours

Unlimited contract

Work-life balance

conflict

\section{Flexible schedule}

Job Insecurity

\section{Household income in euro (categories) ${ }^{10}$.}

In general, would you say your health is...? Five categories, from 'very bad' to 'very good'.

1 if type of occupation is 1,2 or 3 of ISCO codes: worker is

legislator, senior official, manager, professional, technician, or associate professional.

How many hours do you normally work per week in your main job?

1 if worker has an unlimited contract.

Work-life balance conflict. Three categories, from 'no or weak conflict' to 'both work and home conflict'.

1 if worker states s/he can vary her/his start and finish times.

How likely or unlikely does worker think is it that s/he might lose the job in the next 6 months? Five categories, from 'very unlikely'
1

227,624

14.67 (4.67)

3,635

$5 \quad 7,621$

$4.02(0.79)$

3,635

$4.05(0.78)$

3,986

$4.00(0.79)$

1

$0 \quad 7,624 \quad 0.48(0.50)$

0

0

0

0

(1)
to 'very likely'.

Obs. = Observations; $\mathrm{SD}=$ Standard Deviation; Min = minimum; Max = maximum.

\footnotetext{
${ }^{10}$ Annual income categories: $1=$ 'less than $€ 600 ' 2=$ ' $€ 600$ to $€ 1,199 ' 3=' € 1,200$ to $€ 1,799$ ' $4=$ ' $€ 1,800$ to $€ 2,399 ' 5=' € 2,400$ to $€ 2,999 ' 6=$ ' $€ 3,000$ to $€ 4,199 ' 7$ $=$ ' $€ 4,200$ to $€ 5,3999^{\prime} 8=$ ' $€ 5,400$ to $€ 7,199 ' 9=' € 7,200$ to $€ 8,999 ' 10=' € 9,000$ to $€ 10,7999^{\prime} 11=$ ' $€ 10,800$ to $€ 13,499 ' 12=' € 13,500$ to $€ 16,199 ' 13=$ ' $€ 16,200$ to $€ 19,799$ ' $14=$ ' $€ 19,800$ to $€ 23,399 ' 15=' € 23,400$ to $€ 26,999 ' 16=' € 27,000$ to $€ 32,399 ' 17=' € 32,400$ to $€ 37,799 ' 18=' € 37,800$ to $€ 43,199 ' 19=' € 43,200$ to $€ 48,599$ ' $20=$ ' $€ 48,600$ to $€ 53,999 ' 21=$ ' $€ 54,000$ to $€ 65,999 ' 22=$ ' $€ 66,000$ or more'.
} 


\subsection{Empirical model}

Following Rojas (2007) and van Praag et al. (2003) we undertake a two-step strategy to analyse first, the relationship between socioeconomic, demographic and work-related variables, and satisfaction with seven life domains (job, accommodation, health, education, standard of living, family life, social life); and second, the contribution of job satisfaction and non-work-related domains to life satisfaction. We have chosen a two-step methodology, following van Praag and colleagues (2003). Even though some previous studies have used Structural Equation Modelling, SEM, we do not consider SEM a suitable model due to the characteristics of our data (all variables are observed) and the main focus of this paper - on the relationship of work-related characteristics to domain and general life satisfaction, and not the relationship between all explanatory variables and SWB. ${ }^{11}$

Following Rojas (2007), we chose a multiple linear regression analysis for the econometric analysis:

$\mathrm{DS}_{\mathrm{k}}=\mu+\sum_{j}\left[\beta^{j} I C_{i c}^{j}\right]+\sum_{j}\left[\pi^{j} J C_{i c}^{j}\right]+\sum_{j}\left[\rho^{j}\left(H S_{i c} * J C_{i c}^{j}\right]+\varepsilon_{i c}\right.$

To study the contribution of job satisfaction and the various domains to life satisfaction, we follow Rojas (2007), and use a semi-logarithm specification ${ }^{12}$ for modelling the contribution of each domain of life; this takes the following functional form:

$e^{L S}=e^{\alpha} * \prod_{k}\left[D S_{i c}^{\gamma}\right] * e^{\sigma}$

\footnotetext{
${ }^{11}$ Structural equation modelling is an umbrella term that incudes 'methodologies that seek to represent hypotheses about the means, variances and covariances of observed data in terms of a smaller number of 'structural' parameters defined by a hypothesized underlying model' (Kaplan, 2009, p. 1). In our study, all variables (independent, control and dependent variables) are observed - and not psycho-social constructs or latent variables, which are the type of variables SEM was designed to model (Nachtigall et al., 2003). The literature on subjective wellbeing has examples of studies using SEM (Loewe et al., 2014; Rode and Near, 2005) when the dependent variables were not observed and the study of particular paths was not the aim of the research. Two-step models were preferred when all subjective wellbeing variables were observed and the goal was to examine particular relationships - as in the case in this paper, which focuses on the role of work-related variables.

12 "The semi-logarithm specification implies diminishing returns to any domain satisfaction, an increasing marginal rate of substitution between satisfaction in any two domains, and concavity of life satisfaction in domains" (Rojas, 2007, p. 11).
} 
Logarithmic transformation of the equation (2) - taking logarithms in both sides of equation yields equation (3), which is a common way of expressing the semi-logarithm specification.

$L S=\alpha+\ln \left[\sum_{k}\left[\gamma^{k} D S_{i c}\right]\right]+\sigma_{o i c}$

where DS denotes worker's domain satisfaction and LS indicates life satisfaction. The subscript $k$ indicates the domains 1 to 7: job, accommodation, health, education, standard of living, family life and social life. IC denotes the set of individual characteristics, JC the vector of job characteristics, HS high-skilled worker, and $\varepsilon$ and $\sigma$ are the error terms of the two equations. The subscripts $i$ and $c$ indicate the individual worker and country respectively. The subscript $j$ indicates $\mathrm{j}^{\text {th }}$ variable in the vectors of individual and job characteristics.

In the equation (1), among the individual characteristics (IC) that may affect domains of life satisfaction, we control for gender, age, age squared, education level, income and health status. We include among the regressors six work-related variables that have previously been studied in the job satisfaction literature accounting for job characteristics (JC): occupation type, working hours, having an unlimited contract, work-life balance conflict, flexible schedule and job insecurity. In equations (2) and (3), we include the $k$ domains of life satisfaction that may affect life satisfaction: job, accommodation, health, education, standard of living, family life, social life. Figure 2 illustrates the two-step model presented here.

Figure 2. Two-layer model 


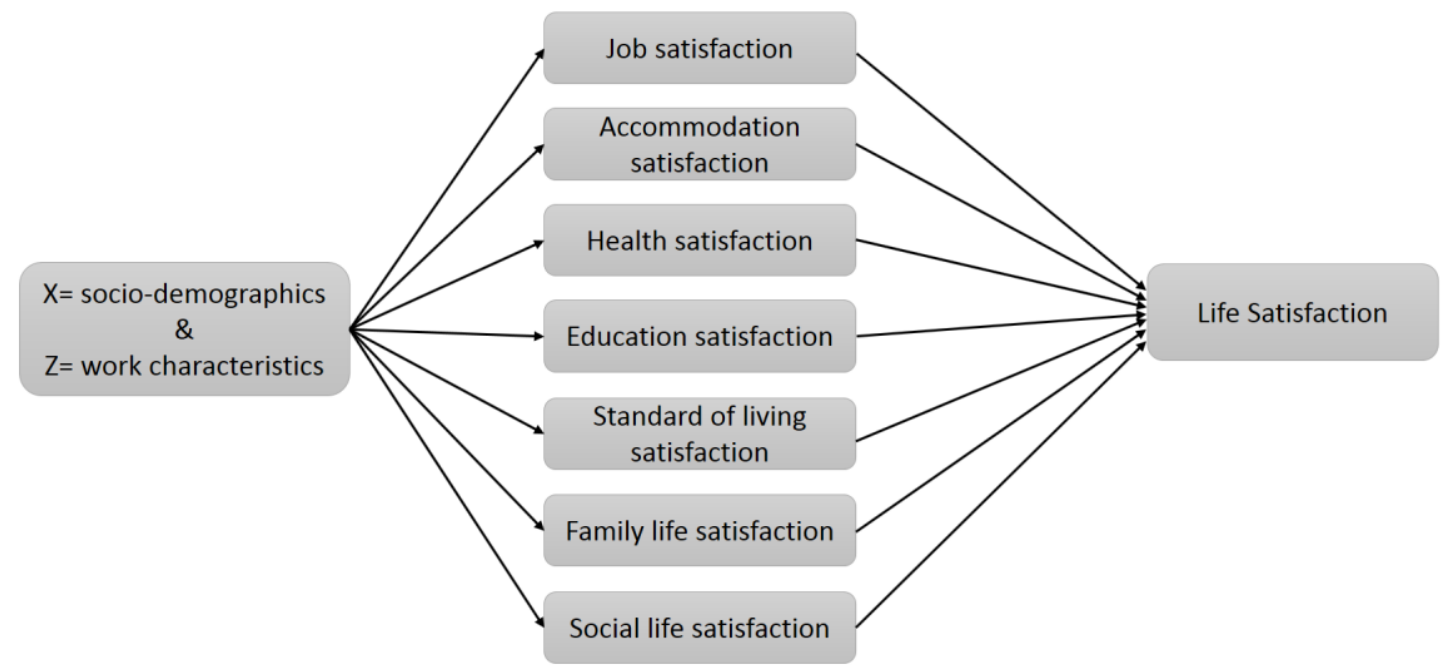

Source: Authors' elaboration following van Praag et al. (2003), Figure 1.

An additional issue to be taken into account concerns the existence of country-level specificities that imply differences in domain satisfaction across countries. Following Rojas (2008), it would be possible for the error term not to be i.i.d. (independently and identically distributed) within each country, which could imply using cluster-robust standard error (CRSE) in the estimation. However, Kézdi (2004) argues that with a small number of clusters (less than 50), inference using the CRSE may be incorrect: estimation that assumes i.i.d. may be preferable. Because the number of clusters in our analysis is less than 50 (28 countries), the econometric results are presented for estimation assuming errors to be independently and identically distributed. Additionally, we have estimated the linear regression model in two different ways in order to assess the robustness of the results: by cluster-robust standard errors (CRSE), and by using a hierarchical linear regression model. These results are available upon request.

\section{Results}

The results of the regression analysis for all domains are presented in Table $2 \mathrm{a}$. All models have also been estimated using an ordered probit model to check the robustness of the results. The coefficients and significance of the estimators did not differ notably between specifications. Hence, following Rojas (2007), we decided to maintain the OLS specification. As Table 2a shows, the 
variables in the model explain some (low to a moderate) variability in domains-of-life satisfaction, as the adjusted $\mathrm{R}^{2}$ coefficients vary from $6.8 \%$ for family life to $41.1 \%$ for health satisfaction. When job-related variables are introduced, the goodness-of-fit increases, particularly concerning satisfaction with standard of living and social life, but remains low regarding satisfaction with accommodation (9\%) and family life (9.6\%), and moderately high concerning health satisfaction $(44.1 \%)$.

As shown in Table 2a, women declare higher satisfaction with education, accommodation job and health than do men. There is a U-shaped relationship between age and accommodation, education standard of living satisfaction and social life, whereas (as expected) health satisfaction declines as workers grow older. The results concerning satisfaction with standard of living and health are in line with Easterlin (2006): individuals with more education report higher levels of satisfaction regarding accommodation, education and standard of living, where satisfaction in other domains does not emerge as dependent on education. Higher income contributes to greater satisfaction in all domains, except for education. Health status is a major contributor to satisfaction across domains, as noted by Frey and Stutzer 2010 and Layard 2010.

As to job characteristics, work-life balance conflict and job insecurity emerge as significant determinants of job satisfaction and of satisfaction with all other domains of life. Workers with higher levels of conflict regarding work-life balance and job insecurity report lower levels of satisfaction across domains. Conflict in the work-life balance emerges as an important determinant of satisfaction with standard of living, social life, job and family life. Specifically, workers moving from "no or weak conflict" to "either work or home conflict" or from "either work or home conflict" to "both work and home conflict" experience a decrease of 0.40 units in their satisfaction with standard of living. This reduction in satisfaction is lowest concerning education: moving from "no or weak conflict" to "either work or home conflict" or from "either work or home conflict" to "both work and home conflict" brings a reduction of 0.18 units in satisfaction with the education domain. Job insecurity is an important determinant of satisfaction with job, standard of living and social life. As job insecurity increases by 1 unit, satisfaction with standard of living decreases by 0.29 units. Moreover, working in a high-skilled occupation is a significant determinant of job, education, standard of living and social life satisfaction. Enjoying a flexible work-schedule is a significant determinant of satisfaction with job, standard of living and social life. Finally, long working hours are positively associated with job satisfaction and negatively with satisfaction with 
family and social life. Having an unlimited contract appears to determine only satisfaction as regards accommodation.

Table 2a. Satisfaction in life-domains, and demographic, socio-economic and work-related variables (OLS)

\begin{tabular}{|c|c|c|c|c|c|c|c|c|}
\hline & \multicolumn{3}{|c|}{ Job } & \multicolumn{3}{|c|}{ Accommodation } & \multicolumn{2}{|c|}{ Health } \\
\hline & \multicolumn{2}{|l|}{ (1) } & (2) & (3) & \multicolumn{2}{|c|}{ (4) } & (5) & (6) \\
\hline \multicolumn{9}{|c|}{ Socio-demographic variables } \\
\hline Male & \multicolumn{2}{|l|}{-0.046} & $-0.236 * * *$ & -0.105 & \multicolumn{2}{|c|}{$-0.142 *$} & -0.071 & $-0.102 *$ \\
\hline Age & \multicolumn{2}{|l|}{-0.027} & -0.017 & $-0.045 * *$ & \multicolumn{2}{|c|}{$-0.040 *$} & $-0.039 * *$ & $-0.029 *$ \\
\hline $\operatorname{Age}^{\wedge} 2$ & \multicolumn{2}{|l|}{$0.049 *$} & 0.029 & $0.080 * * *$ & \multicolumn{2}{|c|}{$0.068^{* *}$} & $0.041 *$ & 0.026 \\
\hline Education level & \multicolumn{2}{|c|}{$0.135 * * *$} & 0.011 & $0.098^{* * *}$ & \multicolumn{2}{|c|}{$0.085^{* *}$} & $0.041^{*}$ & 0.027 \\
\hline Income & \multicolumn{2}{|c|}{$0.055 * * *$} & $0.027 * *$ & $0.074 * * *$ & \multicolumn{2}{|c|}{$0.067 * * *$} & $0.021 * *$ & $0.019 * *$ \\
\hline Health status & \multicolumn{2}{|c|}{$0.450 * * *$} & $0.364 * * *$ & $0.325 * * *$ & \multicolumn{2}{|c|}{$0.271 * * *$} & $1.487 * * *$ & $1.470 * * *$ \\
\hline \multicolumn{9}{|l|}{ Work-related variables } \\
\hline High-skilled worker & \multicolumn{3}{|r|}{$0.422 * * *$} & & \multicolumn{2}{|c|}{0.003} & & 0.070 \\
\hline Working hours & & & $0.007^{*}$ & & -0 . & & & -0.002 \\
\hline Unlimited contract & & & -0.069 & & 0.1 & & & -0.089 \\
\hline Flexible schedule & & & $0.260 * * *$ & & 0. & & & 0.016 \\
\hline $\begin{array}{l}\text { Work-life balance } \\
\text { conflict }\end{array}$ & & & $-0.393^{* * *}$ & & -0.28 & $2 * * *$ & & $-0.241 * * *$ \\
\hline Job insecurity & & & $-0.442 * * *$ & & -0.13 & $1 * * *$ & & $-0.082 * * *$ \\
\hline Intercept & $4.580 * *$ & & 6.516 *** & $5.301 * * *$ & 5.95 & $* * *$ & $2.259 * * *$ & $2.691 * * *$ \\
\hline Adjusted $\mathbf{R}^{2}$ & 0.073 & & 0.170 & 0.074 & 0. & & 0.420 & 0.441 \\
\hline Observations (N) & 7,587 & & 7,280 & 7,587 & 7,2 & & 7,587 & 7,280 \\
\hline & Educ & ation & Standarc & of living & Fam & y life & Soci & al life \\
\hline & (7) & (8) & (9) & (10) & (11) & (12) & (13) & (14) \\
\hline Socio-demographic va & & & & & & & & \\
\hline Male & $-0.190^{* * *}$ & $-0.300 * * *$ & 0.058 & -0.103 & -0.065 & -0.073 & 0.048 & 0.010 \\
\hline Age & $-0.054 * *$ & $-0.045^{*}$ & $-0.094 * * *$ & $-0.087 * * *$ & $-0.037 *$ & -0.025 & $-0.094 * * *$ & $-0.082 * * *$ \\
\hline $\operatorname{Age}^{\wedge} 2$ & $0.073^{* *}$ & $0.058^{* *}$ & $0.117 * * *$ & $0.101 * * *$ & $0.043^{*}$ & 0.025 & $0.117 * * *$ & $0.098^{* * *}$ \\
\hline Education level & $0.583^{* * *}$ & $0.512 * * *$ & $* \quad 0.175^{* * *}$ & $0.092 * * *$ & -0.017 & -0.030 & 0.028 & -0.013 \\
\hline Income & $0.021^{*}$ & 0.010 & $0.126 * * *$ & $0.102 * * *$ & $0.085 * * *$ & $0.081 * * *$ & $0.045^{* * *}$ & $0.035 * * *$ \\
\hline Health status & $0.327 * * *$ & $0.283 * * *$ & $* \quad 0.503 * * *$ & $0.425 * * *$ & $0.398 * * *$ & $0.338 * * *$ & $0.756 * * *$ & $0.692 * * *$ \\
\hline Work-related variable & & & & & & & & \\
\hline High-skilled worker & & $0.375 * * *$ & & $0.288 * * *$ & & 0.008 & & $0.135^{*}$ \\
\hline Working hours & & 0.001 & & 0.004 & & $-0.008 * *$ & & $-0.007 *$ \\
\hline Unlimited contract & & -0.066 & & 0.117 & & 0.006 & & -0.047 \\
\hline Flexible schedule & & 0.070 & & $0.247 * * *$ & & 0.082 & & $0.125^{*}$ \\
\hline
\end{tabular}




\begin{tabular}{|c|c|c|c|c|c|c|c|c|}
\hline \multirow{2}{*}{$\begin{array}{l}\text { Work-life balance } \\
\text { conflict } \\
\text { Job insecurity }\end{array}$} & & \multicolumn{2}{|l|}{$-0.183 * * *$} & \multicolumn{2}{|l|}{$-0.397 * * *$} & \multicolumn{2}{|l|}{$-0.339 * * *$} & $-0.382 * * *$ \\
\hline & & $-0.192 * * *$ & & $-0.292 * * *$ & & $-0.151 * * *$ & & $-0.181 * * *$ \\
\hline Intercept & $4.645^{* * *}$ & $5.581 * * *$ & $4.386 * * *$ & $5.796 * * *$ & $5.658 * * *$ & $6.644 * * *$ & $5.315 * * *$ & $6.525^{* * *}$ \\
\hline Adjusted $\mathbf{R}^{2}$ & 0.168 & 0.194 & 0.185 & 0.245 & 0.068 & 0.096 & 0.147 & 0.183 \\
\hline Observations (N) & 7,587 & 7,280 & 7,587 & 7,280 & 7,587 & 7,280 & 7,587 & 7,280 \\
\hline
\end{tabular}

$* \mathrm{p}<0.05, * * \mathrm{p}<0.01, * * * \mathrm{p}<0.001$. All figures refer to weighted data. Country effects calculated. Robust standard errors were computed. All Variance Inflation Factor, VIFs $\leq 2$.

Source: Authors' calculations, based on 3EQLS micro-data.

To test whether type of occupation (high-skilled/low-skilled) affects the importance of workrelated variables in explaining domain-satisfaction, we included interactions between type of occupation (specifically, a dummy variable identifying 'high-skilled worker') and the five workrelated variables. We added the set of interaction variables in equation 1, including each of these interaction effects alone, and controlling for socio-demographic and work-related variables. Table $2 \mathrm{~b}$ reports the estimated coefficients of these interactions.

Table $2 \mathrm{~b}$ shows that there are minor differences between high- and low-skilled workers on the importance of work-related variables in explaining domain-satisfaction: (1) Among high-skilled workers, satisfaction with social life satisfaction is less negatively affected by job insecurity than is the case among low-skilled workers. (2) Among high-skilled workers, satisfaction with social life satisfaction and health is less negatively affected by long working hours than is the case among low-skilled workers. (3) However, having a flexible schedule has a more positive effect on satisfaction with social life for low-skilled workers than for high-skilled workers.

Table 2b. Satisfaction in life-domains. OLS estimation with interaction variables

\begin{tabular}{|c|c|c|c|c|c|c|c|}
\hline Alternative models & Job & $\begin{array}{c}\text { Accommoda } \\
\text { tion }\end{array}$ & Health & Education & $\begin{array}{c}\text { Standard } \\
\text { of living }\end{array}$ & $\begin{array}{l}\text { Family } \\
\text { life }\end{array}$ & Social life \\
\hline Working hours & 0.005 & -0.001 & $-0.006^{*}$ & 0.003 & $0.005^{\circ}$ & -0.008 & $-0.011 * *$ \\
\hline High-skilled & 0.278 & -0.021 & $-0.341^{*}$ & $0.601 * *$ & 0.331 & 0.015 & $-0.277^{*}$ \\
\hline $\begin{array}{l}\text { Working hours * } \\
\text { High-skilled }\end{array}$ & 0.004 & 0.001 & $0.011^{*}$ & -0.006 & -0.001 & -0.000 & $0.011^{*}$ \\
\hline Unlimited contract & -0.086 & 0.229 & $-0.176^{*}$ & -0.030 & 0.108 & 0.061 & -0.045 \\
\hline High-skilled & $0.384 *$ & 0.086 & -0.118 & $0.454 * *$ & 0.268 & 0.128 & 0.139 \\
\hline $\begin{array}{l}\text { Unlimited contract } \\
* \text { High-skilled }\end{array}$ & 0.043 & -0.094 & 0.215 & -0.091 & 0.023 & -0.138 & -0.005 \\
\hline Flexible schedule & $0.295 * * *$ & 0.120 & 0.016 & 0.113 & $0.289 * * *$ & $0.213^{* *}$ & $0.233 * *$ \\
\hline High-skilled & $0.452 * * *$ & 0.092 & 0.070 & $0.412 * * *$ & $0.324 * * *$ & 0.120 & $0.228 * *$ \\
\hline $\begin{array}{l}\text { Flexible schedule } * \\
\text { High-skilled }\end{array}$ & -0.073 & -0.214 & 0.001 & -0.089 & -0.086 & $-0.271 *$ & $-0.223 *$ \\
\hline
\end{tabular}




\begin{tabular}{|c|c|c|c|c|c|c|c|}
\hline $\begin{array}{l}\text { Work-life balance } \\
\text { conflict }\end{array}$ & $-0.425 * * *$ & $-0.282 * * *$ & $-0.239 * * *$ & $-0.223 * * *$ & $-0.425 * * *$ & $-0.367 * * *$ & $-0.390 * * *$ \\
\hline High-skilled & $0.370 * * *$ & 0.003 & 0.073 & $0.312 * * *$ & $0.245^{* *}$ & -0.037 & 0.123 \\
\hline $\begin{array}{l}\text { Work-life balance } \\
\text { conflict } * \text { High- } \\
\text { skilled }\end{array}$ & 0.075 & -0.000 & -0.005 & 0.090 & 0.062 & 0.064 & 0.017 \\
\hline Job insecurity & $-0.465 * * *$ & $-0.155 * * *$ & $-0.100 * * *$ & $-0.197 * * *$ & $-0.307 * * *$ & $-0.147 * * *$ & $-0.243 * * *$ \\
\hline High-skilled & $0.320 * *$ & -0.106 & -0.009 & $0.350^{* *}$ & $0.220 *$ & 0.025 & $-0.143^{*}$ \\
\hline $\begin{array}{l}\text { Job insecurity * } \\
\text { High-skilled }\end{array}$ & 0.054 & 0.058 & 0.042 & 0.013 & 0.036 & -0.009 & $0.148^{* *}$ \\
\hline
\end{tabular}

Note: all models correspond to models from Table 2a (controlling for socio-demographic and work-related variables) adding the interaction variables stepwise.

$\mathrm{N}=7,280 .{ }^{*} \mathrm{p}<0.05, * * \mathrm{p}<0.01, * * * \mathrm{p}<0.001$. All figures refer to weighted data. Country effects calculated. Robust standard errors were computed. All Variance Inflation Factor, VIFs $\leq 2$.

Source: Authors' calculations, based on 3EQLS micro-data.

Table 3 presents the results of the OLS estimation ${ }^{13}$ of the life-satisfaction equation. We estimated the model after splitting the sample between high-skilled and low-skilled workers. All models estimated are significant ( $\mathrm{p}$-value $<0.001$ ); goodness-of-fit of the regressions is moderately high, as the domains included in the model account for approximately $19 \%$ of the variance in the life-satisfaction variable, slightly higher than the results obtained by Easterlin (2006).

All domains of life except education are shown to be positive and significant in explaining life satisfaction (Table 3). For the whole sample, job satisfaction ranks fourth in explaining life satisfaction, behind satisfaction with standard of living, family life, and social life, in that order. Satisfaction with standard of living - the closest variable we have to income or financial satisfaction - emerges as the most important contributor to life satisfaction for the whole sample, and also when the sample is split between high- and low-skilled workers. Standard of living, family life and social life are still major contributors to life satisfaction for both high- and low-skilled workers. Satisfaction with accommodation, a variable not significant in explaining life satisfaction for high-skilled workers, ranks fourth in importance for low-skilled workers. Interestingly, job satisfaction is relegated to the second-last position as regards importance for life satisfaction among low-skilled workers, with a coefficient $\left(\beta_{1}=0.267\right)$ less than half the size of the coefficient

\footnotetext{
${ }^{13}$ As we did with the work-life characteristics and satisfaction with domains of life regressions (equations 1), we have estimated the linear regression model in two additional ways in order to assess the robustness of the results. First, by cluster-robust stander errors (CRSE); second, by using a hierarchical linear regression model. The results obtained from CRSE estimation and from using a hierarchical linear model are available upon request.

All models were also estimated using an ordered probit model to check the robustness of the results. The coefficients and significance of the estimators did not differ notably between specifications. Hence, following Rojas (2007) we decided to maintain the OLS specification.
} 
of job satisfaction in the high-skilled workers regression $\left(\beta_{1}=0.639\right)$. However, differences in the magnitude of the contribution of life-domains between type of workers are significant only concerning social life.

Table 3. OLS regression analysis: Life satisfaction and satisfaction in domains of life

\begin{tabular}{lcccc}
\hline & All sample & High-skilled & Low-skilled & $\begin{array}{c}\text { Test of } \\
\text { difference } \\
\text { Chi }^{\mathbf{2}}\end{array}$ \\
\hline Job & $0.411^{* * *}$ & $0.639^{* * *}$ & $0.267^{*}$ & $6.060^{*}$ \\
Accommodation & $0.327^{* *}$ & 0.096 & $0.462^{* *}$ & 1.540 \\
Health & $0.381^{* * *}$ & $0.426^{* *}$ & $0.341^{*}$ & 1.510 \\
Education & 0.145 & 0.145 & 0.125 & 0.010 \\
Standard of living & $1.158^{* * *}$ & $1.043^{* * *}$ & $1.250^{* * *}$ & 0.000 \\
Family life & $0.746^{* * *}$ & $0.846^{* * *}$ & $0.686^{* * *}$ & 0.320 \\
Social life & $0.702^{* * *}$ & $0.812^{* * *}$ & $0.623^{* * *}$ & $3.200^{*}$ \\
\hline Intercept & -0.070 & -0.330 & -0.309 & \\
$\mathbf{R}^{2}$ & 0.337 & 0.336 & 0.331 & \\
Adjusted R & 0.190 & 0.188 & 0.183 & \\
Observations (N) & 7,624 & 3,635 & 3,989 & \\
\hline
\end{tabular}

Note: $* \mathrm{p}<0.05, * * \mathrm{p}<0.01, * * * \mathrm{p}<0.001$. All figures refer to weighted data. Country effects calculated. Robust standard errors were computed. All VIFs $\leq 2$. Source: Authors' calculations based on 3EQLS micro-data.

\section{Discussion}

This study has examined the influence of job characteristics on worker satisfaction as regards various life domains and the contribution of the work domain to life satisfaction among a large sample of workers in EU countries, as well as the differences between high- and low-skilled workers in this regard. Four research hypotheses were put forward. Results from regression analysis indicate, in line with $\mathrm{H} 1$, that job characteristics - particularly conflict regarding the work-life balance and job insecurity - are important determinants of satisfaction with the seven domains of the study.

Minor differences emerged between type of workers as regards the influence of work-related indicators, which partly confirms our H2. In particular, satisfaction with social life emerged as the domain with greatest differences between high- and low-skilled workers. Among high-skilled workers, satisfaction with social life satisfaction is less affected by job insecurity or by long working hours than is the case among low-skilled workers. By contrast, having a flexible schedule is more positively associated with social life satisfaction for low-skilled workers than for high- 
skilled workers. Low-skilled workers appear to have fewer opportunities for flexible schedules, as indicated by our literature review (Batinic et al. 2010; Bujacz et al. 2017; Silla et al. 2005). It may well be that low-skilled workers appreciate having flexible work-time arrangements precisely because this is relatively uncommon in their jobs and greatly influences their opportunities to socialize.

Earlier empirical research has found job satisfaction significant in explaining life satisfaction, but it is only in fourth place in our study, confirming our expectations in H3. Satisfaction with standard of living (similar to van Praag et al. and Loewe's financial satisfaction domain) was found to be the most important factor in the studies of Loewe (2014) and van Praag et al. (2003); satisfaction with family life was also an important factor in the studies by Loewe (2014) in Chile and Rojas (2007) in Mexico; and social life (similar to Rojas' domain 'personal satisfaction') was an important factor in Rojas' study. Finally, as hypothesised in our H4, job satisfaction differs in predictive power depending on the type of worker: job satisfaction is important in explaining life satisfaction among high-skilled workers, but the job domain ranks last as regards life satisfaction among low-skilled workers. Further research is needed to explain why low-skilled workers assign relatively less weight to the job satisfaction domain. It might be that, for low-skilled workers, some of the relationship between work characteristics and life satisfaction is captured, not by the work domain but by the relative importance of social life. Among low-skilled workers, satisfaction with social life is strongly linked to work-related variables such as job insecurity, long working hours and job flexibility, thus connecting working conditions to life satisfaction through a non-work domain.

Our study has some important limitations. First, the cross-sectional data may cause problems of endogeneity, as it is difficult to account for unobserved characteristics that may influence both dependent and independent variables and the fact that the independent and dependent variables might cause each other (simultaneity) (Powdthavee 2010). This limits the possibility of interpreting results in causal terms, and could be addressed by using panel data or identifying instrumental variables for each of the job characteristics under study. Second, the third EQLS survey did not include some work-related variables that might be relevant when studying certain domains - specifically, measures related to career prospects or work autonomy. Moreover, future research should incorporate into the analysis the skills-job match variable (skills corresponding/ not corresponding with actual job duties) and preference for type of contract variable (not 
considering temporary workers as a homogeneous group, but differentiating by their preference for temporary work), to grasp better the characteristics of the actual labour market.

This study provides evidence indicating that the increasing insecurity in the job market and the challenges experienced by EU workers in achieving a good work-life balance correlate negatively with satisfaction in every domain of life, in turn determining overall life satisfaction. This is due not solely to their relevance to job satisfaction, but also because of the impact on other domains recognized as important for life satisfaction, such as family life, social life, accommodation and standard of living. Our results indicate that employers and policy-makers concerned with workers' wellbeing should accord greater priority to dealing with the high levels of temporary employment in many EU countries (27\% in Spain, $26 \%$ in Poland, 22\% in, for example, Portugal or the Netherlands; $14 \%$ on average in the EU) ${ }^{14}$ and the difficulties experienced by workers in balancing personal and working life In 2011, 22\% of EU workers surveyed expressed dissatisfaction with their work-life balance: at least several times a month, 53\% reported leaving their workplace too tired to do household jobs; $30 \%$ had difficulties fulfilling family responsibilities due to their working hours; and $14 \%$ found it difficult to concentrate at work because of family responsibilities (Davis, 2013; Eurofound, 2012).

Managers and policy-makers should consider the reasons underlying these negative effects of work-related variables. The negative impacts of greater job insecurity extend across all domains of life. Incentives for companies to offer long-term rather than short-term contracts, as well as measures to protect workers and/or engage them in the future of the company - for example, by discussing clear pathways for promotion - could help to promote both social and company wellbeing. Also the negative impacts of work-life balance conflicts extend across all domains of life. Interventions aimed at improving the work-life balance - such as teleworking to reduce commuting time, or greater autonomy enabling flexibility in the organization of the individual's working time - could foster a better overall work-life balance and serve as powerful instruments for promoting general wellbeing. ${ }^{15}$

\footnotetext{
${ }^{14}$ Percentage of temporary employees in 2017, data from Eurostat, Employment and unemployment (LFS) statistics: http://ec.europa.eu/eurostat/web/lfs/data/database [accessed 20/05/2018]

${ }^{15}$ See Jeffrey et al. (2014) for additional measures to improve wellbeing at work and overall life satisfaction.
} 


\section{References}

Andrews, F. M., \& Withey, S. B. (1976). Social indicators of well-being: Americans'

perceptions of life quality. Springer Science \& Business Media.

Avis, J. (1996). The myth of the post-Fordist society. Knowledge and nationhood, 71-82.

Batinic, B., Selenko, E., Stiglbauer, B., \& Paul, K. I. (2010). Are workers in high-status jobs healthier than others? Assessing Jahoda's latent benefits of employment in two working populations. Work \& Stress, 24(1), 73-87.

Brown, P.; Lauder, H. (1992) Education for economic survival: from Fordism to post-Fordism?. London, New York : Routledge.

Bujacz, A., Bernhard-Oettel, C., Rigotti, T., Magnusson Hanson, L., \& Lindfors, P. (2017). Psychosocial Working Conditions Among High-Skilled Workers: A Latent Transition Analysis. Journal of Occupational Health Psychology. https://doi.org/http://dx.doi.org/10.1037/ocp0000087

Campbell, A., Converse, P. E., \& Rodgers, W. L. (1976). The quality of American life: Perceptions, evaluations, and satisfactions. New York: Russell Sage Foundation.

Clark, A. E. (2010). Work, jobs and well-being across the Millennium. In E. Diener, D. Kahneman, \& J. F. Helliwell (Eds.), International differences in well-being (pp. 436-468) Oxford University Press.

Clark, A. E., \& Oswald, A. J. (1996). Satisfaction and comparison income. Journal of Public Economics, 61, 359-381.

Cummins, R. A. (1996). The domains of life satisfaction: An attempt to order chaos. Social Indicators Research, 38(3), 303-328.

Davies, R. (2013). Work-life balance: Measures to help reconcile work, private and family life. Library of the European Parliament, 130549REV1.

Diener, E. (1984). Subjective well-being. Psychological Bulletin, 95(3), 542-575.

Diener, E. (1996). Traits can be powerful, but are not enough: Lessons from subjective wellbeing. Journal of Research in Personality, 30(3), 389-399.

Diener, E., Suh, E.M., Lucas, R.E. \& Smith, H.L. (1999). Subjective well-being: Three decades of progress. Psychological Bulletin, 125, 276-302.

Dolan, P., Peasgood, T., \& White, M. (2008). Do we really know what makes us happy? A review of the economic literature on the factors associated with subjective well-being. 
Journal of Economic Psychology, 29(1), 94-122.

Drobnič, S., Beham, B., \& Präg, P. (2010). Good Job, Good Life? Working Conditions and Quality of Life in Europe. Social Indicators Research, 99(2), 205-225.

Durkheim, E. (1947). The Division of Labor in Society: (translated by George Simpson). New York: Free Press.

Easterlin, R. A. (2006). Life cycle happiness and its sources: Intersections of psychology, economics, and demography. Journal of Economic Psychology, 27(4), 463-482.

Erdogan, B., Bauer, T. N., Truxillo, D. M., \& Mansfield, L. R. (2012). Whistle While You Work: A Review of the Life Satisfaction Literature. Journal of Management, 38(4), 10381083.

Eurofound. (2010). Coding and classification standards. Retrieved May 10, 2017, from https://www.eurofound.europa.eu/surveys/ewcs/2005/classification

Eurofound. (2012). Third European Quality of Life Survey - Quality of life in Europe: Impacts of the crisis. Publications Office of the European Union, Luxembourg.

Eurofound. (2014). European Quality of Life Survey, 2011-2012. [data collection], 2nd Edition. UK Data Service. European Foundation for the Improvement of Living and Working Conditions. https://doi.org/http://doi.org/10.5255/UKDA-SN-7316-2

Eurofound. (2014). Occupational Profiles in Working Conditions: Identification of Groups with Multiple Disadvantages. Dublin: Publications Office of the European Union.

Eurofound. (2014). Working conditions and job quality: Comparing sectors in Europe. Dublin: Publications Office of the European Union..

Eurofound, \& ILO. (2017). Working anytime, anywhere: The effects on the world of work. Luxembourg,Geneva: Publications Office of the European Union and the International Labour Office. https://doi.org/10.2806/372726

Frey, B. S., \& Stutzer, A. (2002). Happiness and economics: How the economy and institutions affect human well-being. Princeton \& Oxford: Princeton University Press.

Gallie, D., \& Russell, H. (2009). Work-family conflict and working conditions in Western Europe. Social Indicators Research, 93(3), 445-467.

Gough, I., \& McGregor, J. A. (2007). Wellbeing in developing countries. (I. Gough \& J. A. McGregor, Eds.). Cambridge University Press.

Headey, B., Veenhoven, R., \& Wearing, A. (1991). Top-down versus bottom-up theories of 
subjective well-being. Social Indicators Research, 24(1), 81-100.

Heery, E., \& Noon, M. (2008). A Dictionary of Human Resource Management (2nd ed.). Oxford University Press.

Hsieh, C. (2004). To weight or not to weight: The role of domain importance in quality of life measurement. Social Indicators Research, 68(2), 163-174.

Hsieh, C. (2016). Domain Importance in Subjective Well-Being Measures. Social Indicators Research, 127(2), 777-792.

Huang, T.-P. (2011). Comparing motivating work characteristics, job satisfaction, and turnover intention of knowledge workers and blue-collar workers, and testing a structural model of the variables' relationships in China and Japan. The International Journal of Human Resource Management, 22(4), 924-944.

Jeffrey, K., Mahony, S., Michaelson, J., \& Abdallah, S. (2014). Well-being at work. A review of the literature. New Economics Foundation (NEF). ISBN 978-1-908506-57-3.

Kalleberg, A. L. (2009). Precarious Work, Insecure Workers: Employment Relations in Transition. American Sociological Review, 74(1), 1-22.

Kézdi, G. (2004). Robust standard error estimation in fixed-effects panel models. Hungarian Statistical Review, Special Number, 9, 95-116.

Layard, R. (2010). Measuring Subjective Well-Being. Science, 327(1989), 534-535.

Loewe, N., Bagherzadeh, M., Araya-Castillo, L., Thieme, C., \& Batista-Foguet, J. M. (2014). Life Domain Satisfactions as Predictors of Overall Life Satisfaction Among Workers: Evidence from Chile. Social Indicators Research, 118(1), 71-86.

Lopes, H., Lagoa, S., \& Calapez, T. (2014). Work autonomy, work pressure, and job satisfaction: An analysis of European Union countries. The Economic and Labour Relations Review, 25(2), 306-326.

Maertz, C. P., \& Boyar, S. L. (2010). Work-Family Conflict, Enrichment, and Balance under "Levels" and "Episodes" Approaches. Journal of Management, 37(1), 68-98.

Marx, K. (1927). Economic and philosophical manuscripts of 1844. Early writings, 333.

Marx, K. (1976). Capital: A Critique of Political Economy volume one. Penguin Books: London.

Maslow, A. H. (1970). Motivation and personality (2nd ed.). New York: Harper \& Row New York.

McGinnity, F., \& Calvert, E. (2009). Work-life conflict and social inequality in Western Europe. 
Social Indicators Research, 93(3), 489-508.

Michalos, A. C. (1985). Multiple discrepancies theory (MDT). Social Indicators Research, 16(4), 347-413.

Near, J. P., \& Rechner, P. L. (1993). Cross-cultural variations in predictors of life satisfaction: An historical view of differences among West European countries. Social Indicators Research, 29(1), 109-121.

Near, J. P., Rice, R. W., \& Hunt, R. G. (1980). The relationship between work and nonwork domains: A review of empirical research. Academy of Management Review, 5(3), 415-429.

Perrons, D. (2003). The New Economy and the Work-Life Balance: Conceptual Explorations and a Case Study of New Media. Gender, Work \& Organization, 10(1), 65-93.

Powdthavee, N. (2010). How much does money really matter? Estimating the causal effects of income on happiness. Empirical Economics, 39(1), 77-92.

Rode, J. C., \& Near, J. P. (2005). Spillover Between Work Attitudes and Overall Life Attitudes: Myth or Reality? Social Indicators Research, 70(1), 79-109.

Rojas, M. (2006). Life satisfaction and satisfaction in domains of life: is it a simple relationship? Journal of Happiness Studies, 7(4), 467-497.

Rojas, M. (2007). The complexity of well-being: A life-satisfaction conception and a domainsof-life approach. In I. Gough \& J. A. McGregor (Eds.), Well-being in developing countries: From theory to research (pp. 259-280). Cambridge: Cambridge University Press.

Rojas, M. (2008). Relative income and well-being in Latin America. Report for the Latin American Research Network of the Inter-American Development Bank. Puebla, Mexico.

Sennett, R. (1998). The corrosion of character: The personal consequences of work in the new capitalism. New York and London: Norton.

Silla, I., Gracia, F. J., \& Peiró, J. M. (2005). Job Insecurity and Health-Related Outcomes among Different Types of Temporary Workers. Economic and Industrial Democracy, 26(1), 89117.

Sirgy, M. J., Widgery, R. N., Lee, D.-J., \& Yu, G. B. (2010). Developing a measure of community well-being based on perceptions of impact in various life domains. Social Indicators Research, 96(2), 295-311.

Sousa-Poza, A., \& Sousa-Poza, A.A. (2000). Well-being at work: a cross-national analysis of the levels and determinants of job satisfaction. The Journal of Socio-Economics, 29, 517-538. 
Thompson, F. (2003). Fordism, post-Fordism and the flexible system of production. Willamette University. https://www.cddc.vt.edu/digitalfordism/fordism_materials/thompson.htm

van Praag, B. M. S., \& Ferrer-i-Carbonell, A. (2004). Happiness quantified: A satisfaction calculus approach. Oxford University Press.

van Praag, B. M. S., Frijters, P., \& Ferrer-i-Carbonell, A. (2003). The anatomy of subjective well-being. Journal of Economic Behavior and Organization, 51(1), 29-49.

Viñas-Bardolet, C., Torrent-Sellens, J., \& Guillen-Royo, M. (2018). Knowledge Workers and Job Satisfaction: Evidence from Europe. Journal of the Knowledge Economy. https://doi.org/10.1007/s13132-018-0541-1

Voicu, B. (2015). Priming Effects in Measuring Life Satisfaction. Social Indicators Research, 124(3), 993-1013. 


\section{Appendix}

Table A. Pearson's correlations across domains

\begin{tabular}{|c|c|c|c|c|c|c|c|c|}
\hline \multicolumn{9}{|c|}{ Full sample } \\
\hline & 1 & 2 & 3 & 4 & 5 & 6 & 7 & 8 \\
\hline 1. Life Satisfaction & 1 & & & & & & & \\
\hline 2. Job & $0.381 * *$ & 1 & & & & & & \\
\hline 3. Accommodation & $0.382 * *$ & $0.342 * *$ & 1 & & & & & \\
\hline 4. Health & $0.351 * *$ & $0.285^{* *}$ & $0.294 * *$ & 1 & & & & \\
\hline 5. Education & $0.295^{* *}$ & $0.431 * *$ & $0.318 * *$ & $0.270 * *$ & 1 & & & \\
\hline 6. Standard of living & $0.560 * *$ & $0.516^{* *}$ & $0.551 * *$ & $0.368^{* *}$ & $0.405^{* *}$ & 1 & & \\
\hline 7. Family life & $0.429 * *$ & $0.325^{* *}$ & $0.431 * *$ & $0.409 * *$ & $0.276^{* *}$ & $0.444 * *$ & 1 & \\
\hline 8. Social life & $0.446^{* *}$ & $0.377^{* *}$ & $0.388 * *$ & $0.472 * *$ & $0.310 * *$ & $0.487^{* *}$ & $0.472 * *$ & 1 \\
\hline \multicolumn{9}{|c|}{ High-skilled } \\
\hline & 1 & 2 & 3 & 4 & 5 & 6 & 7 & 8 \\
\hline 1. Life Satisfaction & 1 & & & & & & & \\
\hline 2. Job & $0.371 * *$ & 1 & & & & & & \\
\hline 3. Accommodation & $0.380 * *$ & $0.314^{* *}$ & 1 & & & & & \\
\hline 4. Health & $0.368^{* *}$ & $0.279 * *$ & $0.288 * *$ & 1 & & & & \\
\hline 5. Education & $0.281 * *$ & $0.416^{* *}$ & $0.307 * *$ & $0.261^{* *}$ & 1 & & & \\
\hline 6. Standard of living & $0.560 * *$ & $0.465^{* *}$ & $0.563 * *$ & $0.361^{* *}$ & $0.346^{* *}$ & 1 & & \\
\hline 7. Family life & $0.457 * *$ & $0.327^{* *}$ & $0.436^{* *}$ & $0.431 * *$ & $0.282 * *$ & $0.457 * *$ & 1 & \\
\hline 8. Social life & $0.450 * *$ & $0.355^{* *}$ & $0.378 * *$ & $0.478 * *$ & $0.281 * *$ & $0.445^{* *}$ & $0.479 * *$ & 1 \\
\hline \multicolumn{9}{|c|}{ Low-skilled } \\
\hline & 1 & 2 & 3 & 4 & 5 & 6 & 7 & 8 \\
\hline 1. Life Satisfaction & 1 & & & & & & & \\
\hline 2. Job & $0.366^{* *}$ & 1 & & & & & & \\
\hline 3. Accommodation & $0.374 * *$ & $0.349 * *$ & 1 & & & & & \\
\hline 4. Health & $0.332 * *$ & $0.280^{* *}$ & $0.293 * *$ & 1 & & & & \\
\hline 5. Education & $0.271 * *$ & $0.401^{* *}$ & $0.311^{* *}$ & $0.267 * *$ & 1 & & & \\
\hline 6. Standard of living & $0.543 * *$ & $0.522 * *$ & $0.537 * *$ & $0.366^{* *}$ & $0.397 * *$ & 1 & & \\
\hline 7. Family life & $0.404 * *$ & $0.317^{* *}$ & $0.423 * *$ & $0.388^{* *}$ & $0.265 * *$ & $0.433^{* *}$ & 1 & \\
\hline 8. Social life & $0.437 * *$ & $0.386^{* *}$ & $0.390 * *$ & $0.463 * *$ & $0.323 * *$ & $0.514^{* *}$ & $0.463 * *$ & 1 \\
\hline
\end{tabular}

Significance level: $* * 1 \%$. 
Table B. Indicators and domains, Pearson's correlations

\begin{tabular}{|c|c|c|c|c|c|c|c|c|c|c|}
\hline & Male & Age & $\begin{array}{c}\text { Education } \\
\text { level^^}^{\wedge}\end{array}$ & Income $^{\wedge}$ & $\begin{array}{l}\text { Health } \\
\text { status }^{\wedge}\end{array}$ & $\begin{array}{l}\text { Working } \\
\text { hours }\end{array}$ & $\begin{array}{l}\text { Unlimited } \\
\text { contract }\end{array}$ & $\begin{array}{l}\text { Work-life } \\
\text { balance } \\
\text { conflict }^{\wedge}\end{array}$ & $\begin{array}{l}\text { Flexible } \\
\text { schedule }\end{array}$ & $\begin{array}{c}\text { Job } \\
\text { security }^{\wedge}\end{array}$ \\
\hline Male & 1 & & & & & & & & & \\
\hline Age & 0.002 & 1 & & & & & & & & \\
\hline Education level^ & 0.004 & $-0.040 * *$ & 1 & & & & & & & \\
\hline Income $^{\wedge}$ & $0.079 * *$ & $0.080 * *$ & $0.185 * *$ & 1 & & & & & & \\
\hline 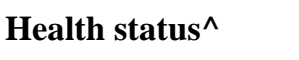 & $0.067 * *$ & $-0.252 * *$ & $0.091 * *$ & $0.156^{* *}$ & 1 & & & & & \\
\hline Working hours & $0.249 * *$ & $-0.041 * *$ & $0.042 * *$ & $-0.118 * *$ & 0.017 & 1 & & & & \\
\hline Unlimited contract & $0.033 * *$ & $0.151 * *$ & $0.037 * *$ & $0.056 * *$ & $-0.043 * *$ & $0.071 * *$ & 1 & & & \\
\hline 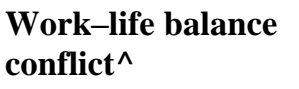 & $-0.098 * *$ & $-0.068 * *$ & -0.019 & $-0.108 * *$ & $-0.125 * *$ & $0.132 * *$ & $-0.026 *$ & 1 & & \\
\hline Flexible schedule & $0.094 * *$ & $0.029 *$ & $0.117 * *$ & $0.244 * *$ & $0.046 * *$ & $-0.023^{*}$ & $0.046 * *$ & $-0.086 * *$ & 1 & \\
\hline Job insecurity $^{\wedge}$ & $-0.042 * *$ & $-0.079 * *$ & $-0.104 * *$ & $-0.257 * *$ & $-0.077 * *$ & $0.069 * *$ & $-0.173 * *$ & $0.120 * *$ & $-0.107 * *$ & 1 \\
\hline Life Satisfaction & $0.030 * *$ & -0.011 & $0.113 * *$ & $0.306 * *$ & $0.245 * *$ & $-0.064 * *$ & $0.060 * *$ & $-0.201 * *$ & $0.158 * *$ & $-0.250 * *$ \\
\hline Job & 0.004 & $0.068 * *$ & $0.134 * *$ & $0.146 * *$ & $0.155 * *$ & 0.012 & $0.067 * *$ & $-0.187 * *$ & $0.118 * *$ & $-0.268 * *$ \\
\hline Accommodation & 0.003 & $0.104 * *$ & $0.092 * *$ & $0.189 * *$ & $0.154 * *$ & $-0.032 * *$ & $0.060 * *$ & $-0.153 * *$ & $0.070 * *$ & $-0.150 * *$ \\
\hline Health & $0.048 * *$ & $-0.176^{* *}$ & $0.094 * *$ & $0.118 * *$ & $0.642 * *$ & 0.021 & -0.021 & $-0.162 * *$ & $0.055^{* *}$ & $-0.093 * *$ \\
\hline Education & -0.021 & 0.006 & $0.359 * *$ & $0.109 * *$ & $0.154 * *$ & 0.012 & $0.050 * *$ & $-0.089 * *$ & $0.067 * *$ & $-0.169 * *$ \\
\hline Standard of living & $0.047 * *$ & 0.018 & $0.188 * *$ & $0.381 * *$ & $0.225 * *$ & $-0.027^{*}$ & $0.078 * *$ & $-0.216^{* *}$ & $0.172 * *$ & $-0.279 * *$ \\
\hline Family life & 0.010 & -0.005 & $0.056 * *$ & $0.149 * *$ & $0.189 * *$ & -0.020 & $0.033 * *$ & $-0.134 * *$ & $0.058 * *$ & $-0.137 * *$ \\
\hline Social life & $0.041 * *$ & $-0.060 * *$ & $0.058 * *$ & $0.141 * *$ & $0.319 * *$ & $-0.044 * *$ & 0.014 & $-0.198 * *$ & $0.087 * *$ & $-0.167 * *$ \\
\hline
\end{tabular}

$\wedge \wedge$ Spearman's correlation coefficient is calculated. * Correlation significant at $5 \%$. ** Correlation significant at $1 \%$. 
Table C. Likert-type scales: Life and domains-of-life satisfaction responses

\begin{tabular}{|c|c|c|c|c|c|c|}
\hline \multirow[t]{2}{*}{ Life satisfaction } & \multicolumn{2}{|c|}{ FULL SAMPLE } & \multicolumn{2}{|c|}{ HIGH-SKILLED } & \multicolumn{2}{|c|}{ LOW-SKILLED } \\
\hline & Freq. & Percent & Freq. & Percent & Freq. & Percent \\
\hline 1 - very dissatisfied & 62 & 0.81 & 14 & 0.39 & 48 & 1.20 \\
\hline 2 & 79 & 1.04 & 20 & 0.55 & 59 & 1.48 \\
\hline 3 & 167 & 2.19 & 58 & 1.60 & 109 & 2.73 \\
\hline 4 & 221 & 2.90 & 79 & 2.17 & 142 & 3.56 \\
\hline 5 & 621 & 8.15 & 240 & 6.6 & 381 & 9.55 \\
\hline 6 & 697 & 9.14 & 282 & 7.76 & 415 & 10.4 \\
\hline 7 & 1,595 & 20.92 & 727 & 20.00 & 868 & 21.76 \\
\hline 8 & 2,246 & 29.46 & 1,166 & 32.08 & 1,080 & 27.07 \\
\hline 9 & 1,169 & 15.33 & 672 & 18.49 & 497 & 12.46 \\
\hline 10 - very satisfied & 767 & 10.06 & 377 & 10.37 & 390 & 9.78 \\
\hline Total & 7,624 & $100 \%$ & 3,635 & $100 \%$ & 3,989 & $100 \%$ \\
\hline \multirow[t]{2}{*}{ Job satisfaction } & \multicolumn{2}{|c|}{ FULL SAMPLE } & \multicolumn{2}{|c|}{ HIGH-SKILLED } & \multicolumn{2}{|c|}{ LOW-SKILLED } \\
\hline & Freq. & Percent & Freq. & Percent & Freq. & Percent \\
\hline 1 - very dissatisfied & 79 & 1.04 & 20 & 0.55 & 59 & 1.48 \\
\hline 2 & 100 & 1.31 & 32 & 0.88 & 68 & 1.70 \\
\hline 3 & 145 & 1.90 & 45 & 1.24 & 100 & 2.51 \\
\hline 4 & 175 & 2.30 & 61 & 1.68 & 114 & 2.86 \\
\hline 5 & 567 & 7.44 & 162 & 4.46 & 405 & 10.15 \\
\hline 6 & 649 & 8.51 & 246 & 6.77 & 403 & 10.10 \\
\hline 7 & 1,344 & 17.63 & 573 & 15.76 & 771 & 19.33 \\
\hline 8 & 1,965 & 25.77 & 1,020 & 28.06 & 945 & 23.69 \\
\hline 9 & 1,212 & 15.90 & 708 & 19.48 & 504 & 12.63 \\
\hline 10 - very satisfied & 1,388 & 18.21 & 768 & 21.13 & 620 & 15.54 \\
\hline Total & 7,624 & $100 \%$ & 3,635 & $100 \%$ & 3,989 & $100 \%$ \\
\hline \multirow{2}{*}{ Accommodation satisfaction } & \multicolumn{2}{|c|}{ FULL SAMPLE } & \multicolumn{2}{|c|}{ HIGH-SKILLED } & \multicolumn{2}{|c|}{ LOW-SKILLED } \\
\hline & Freq. & Percent & Freq. & Percent & Freq. & Percent \\
\hline 1 - very dissatisfied & 61 & 0.80 & 26 & 0.72 & 35 & 0.88 \\
\hline 2 & 73 & 0.96 & 23 & 0.63 & 50 & 1.25 \\
\hline 3 & 144 & 1.89 & 58 & 1.60 & 86 & 2.16 \\
\hline 4 & 191 & 2.51 & 62 & 1.71 & 129 & 3.23 \\
\hline 5 & 496 & 6.51 & 202 & 5.56 & 294 & 7.37 \\
\hline 6 & 566 & 7.42 & 250 & 6.88 & 316 & 7.92 \\
\hline 7 & 1,261 & 16.54 & 558 & 15.35 & 703 & 17.62 \\
\hline 8 & 1,844 & 24.19 & 931 & 25.61 & 913 & 22.89 \\
\hline 9 & 1,393 & 18.27 & 725 & 19.94 & 668 & 16.75 \\
\hline 10 - very satisfied & 1,595 & 20.92 & 800 & 22.01 & 795 & 19.93 \\
\hline Total & 7,624 & $100 \%$ & 3,635 & $100 \%$ & 3,989 & $100 \%$ \\
\hline \multirow[t]{2}{*}{ Health satisfaction } & \multicolumn{2}{|c|}{ FULL SAMPLE } & \multicolumn{2}{|c|}{ HIGH-SKILLED } & \multicolumn{2}{|c|}{ LOW-SKILLED } \\
\hline & Freq. & Percent & Freq. & Percent & Freq. & Percent \\
\hline 1 - very dissatisfied & 41 & 0.54 & 10 & 0.28 & 31 & 0.78 \\
\hline 2 & 54 & 0.71 & 22 & 0.61 & 32 & 0.8 \\
\hline 3 & 112 & 1.47 & 44 & 1.21 & 68 & 1.7 \\
\hline 4 & 170 & 2.23 & 78 & 2.15 & 92 & 2.31 \\
\hline 5 & 437 & 5.73 & 174 & 4.79 & 263 & 6.59 \\
\hline 6 & 533 & 6.99 & 233 & 6.41 & 300 & 7.52 \\
\hline 7 & 1,030 & 13.51 & 470 & 12.93 & 560 & 14.04 \\
\hline 8 & 1,830 & 24.00 & 894 & 24.59 & 936 & 23.46 \\
\hline 9 & 1,639 & 21.50 & 841 & 23.14 & 798 & 20.01 \\
\hline 10 - very satisfied & 1,778 & 23.32 & 869 & 23.91 & 909 & 22.79 \\
\hline Total & 7,624 & $100 \%$ & 3,635 & $100 \%$ & 3,989 & $100 \%$ \\
\hline
\end{tabular}




\begin{tabular}{|c|c|c|c|c|c|c|}
\hline \multirow[t]{2}{*}{ Education satisfaction } & \multicolumn{2}{|c|}{ FULL SAMPLE } & \multicolumn{2}{|c|}{ HIGH-SKILLED } & \multicolumn{2}{|c|}{ LOW-SKILLED } \\
\hline & Freq. & Percent & Freq. & Percent & Freq. & Percent \\
\hline 1 - very dissatisfied & 96 & 1.26 & 22 & 0.61 & 74 & 1.86 \\
\hline 2 & 83 & 1.09 & 19 & 0.52 & 64 & 1.6 \\
\hline 3 & 165 & 2.16 & 43 & 1.18 & 122 & 3.06 \\
\hline 4 & 245 & 3.21 & 70 & 1.93 & 175 & 4.39 \\
\hline 5 & 655 & 8.59 & 192 & 5.28 & 463 & 11.61 \\
\hline 6 & 618 & 8.11 & 213 & 5.86 & 405 & 10.15 \\
\hline 7 & 1,277 & 16.75 & 512 & 14.09 & 765 & 19.18 \\
\hline 8 & 1,742 & 22.85 & 895 & 24.62 & 847 & 21.23 \\
\hline 9 & 1,071 & 14.05 & 656 & 18.05 & 415 & 10.40 \\
\hline 10 - very satisfied & 1,672 & 21.93 & 1,013 & 27.87 & 659 & 16.52 \\
\hline Total & 7,624 & $100 \%$ & 3,635 & $100 \%$ & 3,989 & $100 \%$ \\
\hline \multirow[t]{2}{*}{ Standard of living satisfaction } & \multicolumn{2}{|c|}{ FULL SAMPLE } & \multicolumn{2}{|c|}{ HIGH-SKILLED } & \multicolumn{2}{|c|}{ LOW-SKILLED } \\
\hline & Freq. & Percent & Freq. & Percent & Freq. & Percent \\
\hline 1 - very dissatisfied & 96 & 1.26 & 27 & 0.74 & 69 & 1.73 \\
\hline 2 & 105 & 1.38 & 27 & 0.74 & 78 & 1.96 \\
\hline 3 & 216 & 2.83 & 65 & 1.79 & 151 & 3.79 \\
\hline 4 & 301 & 3.95 & 97 & 2.67 & 204 & 5.11 \\
\hline 5 & 720 & 9.44 & 243 & 6.69 & 477 & 11.96 \\
\hline 6 & 818 & 10.73 & 341 & 9.38 & 477 & 11.96 \\
\hline 7 & 1,517 & 19.90 & 669 & 18.40 & 848 & 21.26 \\
\hline 8 & 1,908 & 25.03 & 1,010 & 27.79 & 898 & 22.51 \\
\hline 9 & 1,034 & 13.56 & 615 & 16.92 & 419 & 10.50 \\
\hline 10 - very satisfied & 909 & 11.92 & 541 & 14.88 & 368 & 9.23 \\
\hline Total & 7,624 & $100 \%$ & 3,635 & $100 \%$ & 3,989 & $100 \%$ \\
\hline \multirow[t]{2}{*}{ Family life satisfaction } & \multicolumn{2}{|c|}{ FULL SAMPLE } & \multicolumn{2}{|c|}{ HIGH-SKILLED } & \multicolumn{2}{|c|}{ LOW-SKILLED } \\
\hline & Freq. & Percent & Freq. & Percent & Freq. & Percent \\
\hline 1 - very dissatisfied & 60 & 0.79 & 29 & 0.8 & 31 & 0.78 \\
\hline 2 & 74 & 0.97 & 24 & 0.66 & 50 & 1.25 \\
\hline 3 & 135 & 1.77 & 55 & 1.51 & 80 & 2.01 \\
\hline 4 & 158 & 2.07 & 71 & 1.95 & 87 & 2.18 \\
\hline 5 & 372 & 4.88 & 155 & 4.26 & 217 & 5.44 \\
\hline 6 & 473 & 6.20 & 209 & 5.75 & 264 & 6.62 \\
\hline 7 & 992 & 13.01 & 434 & 11.94 & 558 & 13.99 \\
\hline 8 & 1,657 & 21.73 & 792 & 21.79 & 865 & 21.68 \\
\hline 9 & 1,580 & 20.72 & 829 & 22.81 & 751 & 18.83 \\
\hline 10 - very satisfied & 2,123 & 27.85 & 1,037 & 28.53 & 1,086 & 27.22 \\
\hline Total & 7,624 & $100 \%$ & 3,635 & $100 \%$ & 3,989 & $100 \%$ \\
\hline \multirow[t]{2}{*}{ Social life satisfaction } & \multicolumn{2}{|c|}{ FULL SAMPLE } & \multicolumn{2}{|c|}{ HIGH-SKILLED } & \multicolumn{2}{|c|}{ LOW-SKILLED } \\
\hline & Freq. & Percent & Freq. & Percent & Freq. & Percent \\
\hline 1 - very dissatisfied & 61 & 0.8 & 20 & 0.55 & 41 & 1.03 \\
\hline 2 & 78 & 1.02 & 32 & 0.88 & 46 & 1.15 \\
\hline 3 & 170 & 2.23 & 59 & 1.62 & 111 & 2.78 \\
\hline 4 & 242 & 3.17 & 101 & 2.78 & 141 & 3.53 \\
\hline 5 & 623 & 8.17 & 267 & 7.35 & 356 & 8.92 \\
\hline 6 & 768 & 10.07 & 349 & 9.60 & 419 & 10.50 \\
\hline 7 & 1,378 & 18.07 & 664 & 18.27 & 714 & 17.90 \\
\hline 8 & 1,935 & 25.38 & 954 & 26.24 & 981 & 24.59 \\
\hline 9 & 1,200 & 15.74 & 627 & 17.25 & 573 & 14.36 \\
\hline 10 - very satisfied & 1,169 & 15.33 & 562 & 15.46 & 607 & 15.22 \\
\hline Total & 7,624 & $100 \%$ & 3,635 & $100 \%$ & 3,989 & $100 \%$ \\
\hline
\end{tabular}


Table D. Occupation Mean Comparison: results from T-test across domains

\begin{tabular}{lcccccc}
\hline & $\begin{array}{c}\text { Full } \\
\text { sample, } \\
\text { mean }\end{array}$ & $\begin{array}{c}\text { High- } \\
\text { skilled, } \\
\text { mean }\end{array}$ & $\begin{array}{c}\text { Low- } \\
\text { skilled, } \\
\text { mean }\end{array}$ & $\begin{array}{c}\text { Variance } \\
\text { homogeneity } \\
\text { Levene statistic } \\
\text { (Sig) }\end{array}$ & $\begin{array}{c}\text { T-test t (Sig.) - } \\
\text { assuming equal } \\
\text { variance }\end{array}$ & $\begin{array}{c}\text { T-test t (Sig.) - Not } \\
\text { assuming equal } \\
\text { variance }\end{array}$ \\
\hline Life Satisfaction & 7.37 & 7.61 & 7.16 & $67.32^{*}$ & $11.12^{*}$ & $11.20^{*}$ \\
\hline Job & 7.62 & 7.97 & 7.29 & $140.79^{*}$ & $15.52^{*}$ & $15.64^{*}$ \\
Accommodation & 7.78 & 7.95 & 7.64 & $59.20^{*}$ & $7.10^{*}$ & $7.13^{*}$ \\
Health & 7.99 & 8.11 & 7.89 & $28.25^{*}$ & $5.26^{*}$ & $5.28^{*}$ \\
Education & 7.60 & 8.11 & 7.14 & $131.97^{*}$ & $21.38^{*}$ & $21.56^{*}$ \\
Standard of living & 7.21 & 7.60 & 6.85 & $57.77^{*}$ & $16.95^{*}$ & $17.05^{*}$ \\
Family life & 8.08 & 8.19 & 7.98 & $9.48^{*}$ & $4.73^{*}$ & $4.75^{*}$ \\
Social life & 7.48 & 7.60 & 7.37 & $30.67^{*}$ & $5.34^{*}$ & $5.36^{*}$ \\
\hline
\end{tabular}

* two-tailed significance level at 5\%. 